\title{
Synthesis, characterisation and microbial studies of [bis(1,10-phenanthroline) (ethylenediamine) copper(II)] diperchlorate and its bromide analogue
}

\author{
Oluwayemi O. Esther Onawumi", Idowu O. Adeoye, Florence A. Oluwafunmilayo Adekunle \\ Department of Pure and Applied Chemistry, Ladoke Akintola University of Technology, Ogbomoso, Nigeria \\ Email: ${ }^{*}$ estherdr@rocketmail.com
}

Received 17 August 2012; revised 22 September 2012; accepted 10 October 2012

\begin{abstract}
Two new tris-chelate-complexes have been synthesized and characterized with elemental and spectroscopic methods. IR and thermal studies correlate with the structures of the complex in the solid state. The structure of $\left[\mathrm{Cu}(\mathrm{en})(\mathrm{phen})_{2}\right] \cdot 2 \mathrm{ClO}_{4}^{-}$was determined with $X$-ray data using single crystal $X$-ray diffractometer while the molecular structure of $[\mathrm{Cu}(\mathrm{en})$ $\left.(\text { phen })_{2}\right] \cdot 2 \mathrm{Br}^{-} \cdot 2 \mathrm{Phen} \cdot 8 \mathrm{H}_{2} \mathrm{O}$ was deduced from the used characterization methods. $\left[\mathrm{Cu}(\mathrm{en})(\mathrm{phen})_{2}\right] \cdot \mathrm{ClO}_{4}^{-}$crystallizes as orthorhombic with space group Pben. Both complexes have distorted octahedral geometry. Microbial activities of these complexes against Staphylococcus aureus, Escherichia coli, Pseudomonas aeruginosa, Streptoccocus pyogeneous, Candida albicans, and Aspergillus niger were also reported.
\end{abstract}

Keywords: Tris-Chelate Complexes; X-Ray Data; Electronic Spectra; Microbial Studies

\section{INTRODUCTION}

Copper(II) ions and its metal complexes have continued to attract attention of coordination chemists due to its various interesting structural features, its usefulness as models of the active centers of various metallo-enzymes, magnetic, electronic, catalytic and biological properties [1-3].

In recent times, Copper(II) complexes from various ligand systems such as 1,10-phenanthroline and 1,2-diaminoethane have been synthesized and characterized with the aim of gaining a better understanding of the chemistry of copper and the various ligands in different environments.

We have previously described [4] the synthesis and spectral studied of tris chelate of mixed-ligand complexes of copper(II) ion of nitrate and that of chloride with 1,2-diaminoethane and 1,10-phenanthroline in which

"Corresponding author. the H-bonded network of lattice water molecules and the anions in both compounds are quite different from one another. The $\mathrm{NO}_{3}^{-}, \mathrm{H}_{2} \mathrm{O}, \mathrm{H}$-bonded network has a $1 \mathrm{D}$ chain structure while $\mathrm{Cl}^{-}, \mathrm{H}_{2} \mathrm{O}$ network has a $3 \mathrm{D}$ structure. The change in the structure is due to the change in the size of anions as $\mathrm{Cl}^{-}$ions allow very close $\mathrm{H}$-bonding because of its smaller size compare to $\mathrm{NO}_{3}^{-}$. We are considering the effect of $\mathrm{ClO}_{4}^{-}$ion upon these supramolecular structures. The activities of these two complexes on micro-organisms such as Staphylococcus aureus, Escherichia coli, Pseudomonas aeruginosa, Streptoccocus pyogeneous, Candida albicans, and Aspergillus niger being the micro-organisms that affect man and plants were also carried out.

In this paper, we therefore report the synthesis, characterization, structure, and microbial studies of $[\mathrm{Cu}(\mathrm{en})$ (phen $\left.)_{2}\right]\left(\mathrm{ClO}_{4}\right)_{2}-(1)$ and

$\left[\mathrm{Cu}(\mathrm{en})(\text { phen })_{2}\right] 2 \mathrm{Br} \cdot 2 \mathrm{Phen} \cdot 8 \mathrm{H}_{2} \mathrm{O}-(2)$.

\section{EXPERIMENTAL}

All the chemicals used, were analytical reagent from commercial sample. They were procured from Fluka and Merck. The reagents were used without further purification.

\subsection{Synthesis of $\left[\mathrm{Cu}(\mathrm{en})(\mathrm{phen})_{2}\right]\left(\mathrm{ClO}_{4}\right)_{2}(1)$}

$\mathrm{Cu}\left(\mathrm{ClO}_{4}\right)_{2} \cdot 6 \mathrm{H}_{2} \mathrm{O}(0.370 \mathrm{~g}, 1 \mathrm{mmol})$ and 1,2-diaminoethane $(0.20 \mathrm{~mL}, 2.92 \mathrm{mmol})$ were dissolved in $25 \mathrm{~mL}$ water and heated to $80^{\circ} \mathrm{C}$ for 10 mins with stirring. To this, $5 \mathrm{~mL}$ ethanolic solution of 1,10-phenanthroline $(0.198$ g, $1.00 \mathrm{mmol}$ ) was added and stirred for another $5 \mathrm{mins}$ and the solution was filtered. There was blue precipitate. The precipitate was recrystallized with methanol. Greenish blue block shaped X-ray type crystals were obtained after four days. Yield: $0.3576 \mathrm{~g}(52.35 \%)$. Anal. calcd. for $\mathrm{C}_{26} \mathrm{H}_{24} \mathrm{CuN}_{6} \mathrm{Cl}_{2} \mathrm{O}_{8}$ :

C 45.73, H, 3.54; N, 12.31, Found: C 45.72; H, 3.50; $\mathrm{N}, 12.27$.

IR (KBr disk, $\left.\mathrm{cm}^{-1}\right)$ : 3393, 3312, 2953, 2853, 1622, 
$1585,1507,1094,843,728,422$.

\subsection{Synthesis of $\left[\mathrm{Cu}(\mathrm{en})(\mathrm{phen})_{2}\right] \cdot 2 \mathrm{Br}^{-} \cdot 2($ phen $) \cdot 8 \mathrm{H}_{2} \mathrm{O}(2)$}

The procedure was similar to that of 1 , except for the use of $\mathrm{CuBr}_{2},(0.223 \mathrm{~g}, 1 \mathrm{mmole})$. Blue crystals in the form of hexagonal shaped were obtained from the filtrate after four days Similar crystals were obtained when the synthesis was carried out with the reagent in ratio 1:1:4. of $\mathrm{Cu}$ :en:phen in order to maximize the yield. Yield: $0.1857 \mathrm{~g}(64.68 \%)$. Anal. calcd. for $\mathrm{C}_{50} \mathrm{H}_{56} \mathrm{Br}_{2} \mathrm{CuN}_{10} \mathrm{O}_{8}$ : C, 52.29; H, 4.91; N, 12.19 Found: C, 52.19; H, 4.88; N, 12.14 .

IR ( $\mathrm{KBr}$ disk, $\left.\mathrm{cm}^{-1}\right)$ : 3403, 3226, 3093, 1623, 1585, 1506, 1420, 846, 727, 420.

\subsection{Physical Measurements}

IR spectra were recorded using $\mathrm{KBr}$ discs on a Perkin Elmer, GX-FTIR spectrometer in the range $4000-400$ $\mathrm{cm}^{-1}$. Elemental analysis for $\mathrm{C}, \mathrm{H}$ and $\mathrm{N}$ was performed on a Perkin-Elmer, Series II, 2400. Electronic spectra measurements were obtained using a Shimadzu UV-3101 PC spectrophotometer. Thermogravimetric analysis was done using Mettler Toledo.

\subsection{X-Ray Crystallography}

X-ray data were collected on a Bruker SMART APEX CCD X-ray diffractometer, using graphite-monochromated Mo-K $\alpha$ radiation $(\lambda=0.71073 \AA)$ at $298 \mathrm{~K}$. Data were reduced using SAINTPLUS [5] and a multi-scan absorption correction using SADABS [6] was performed. The structures were solved by direct method using SHELXS97 and full-matrix least-square refinement was carried out using SHELXL-97. [7] All ring hydrogen atoms were assigned on the basis of geometrical considerations and were allowed to ride upon the respective carbon atoms. Drawings were made using Mercury [8].

\subsection{Antimicrobial Screening}

The antimicrobial screening was performed by paper diffusion method. The activities were expressed in terms of millimeter $(\mathrm{mm})$ by diameter of zone of inhibition. Ampicilline, Chloramphenicol, Ciprofloxacin and Norfloxacin were used as standard drugs for bacteria. Greseofulvin and Nystatin were used for fungi.

\subsubsection{Microorganisms Used}

The following common standard strains were used for screening of antibacterial and antifungal activities. The strains, listed below, were procured from Institute of Microbial Technology, Chandigarh India. The bacteria used are 1) Staphylococcus aureus MTCC 96;2) Es- cherichia coli MTCC 443; 3) Pseudomonas aeruginosa MTCC 1688; and 4) Streptoccocus pyogeneous MTCC 442, while fungi used are 5) Candida albicans MTCC 227; and 6) Aspergillus niger MTCC 282.

\subsubsection{Culture Media}

Nutrient agar medium was prepared by dissolving $7.0 \mathrm{~g}$ of agar powder in $250 \mathrm{~mL}$ of distilled water in a conical flask (for bacteria). Potato dextrose agar medium was prepared by dissolving $9.75 \mathrm{~g}$ of potato dextrose agar powder in $250 \mathrm{~mL}$ of distilled water in a conical flask (for fungi). The conical flask was capped with cotton wool and aluminium foil and then sterilized in an autoclave for 15 minutes at $121^{\circ} \mathrm{C}$.

Using an inoculate wire loop, the micro organisms were collected from slant cultures of all the different micro-organisms and were inoculated separately into fresh sterile nutrient broths for bacteria and the resulting cultures were incubated at $37^{\circ} \mathrm{C}$ for $18 \mathrm{hrs}$ and at room temperature to obtain new cultures of bacteria respectively.

\subsubsection{Zone of Inhibition}

The zone of inhibition of the complexes was carried out by dipping sterile paper disc into a range of metal complexes solutions using sterile forceps. These were then carefully and aseptically laid on the media flooded with cultures of test organisms. The concentrations used were $250,100,50,25$ and $5 \mu \mathrm{g} / \mathrm{mL}$ and finally, the Petri plates were incubated for $26-30 \mathrm{hrs}$, at $28^{\circ} \mathrm{C} \pm 2^{\circ} \mathrm{C}$. The zone of inhibition was measured in millimetre. The results are shown in Table 3 for bacteria and Table $\mathbf{4}$ for the fungi.

\section{RESULTS AND DISCUSSION}

\subsection{Synthesis}

The two complexes were prepared by a similar method of synthesis using the reagents in molar ratio of 1:3:1. of $\mathrm{Cu}^{2+}$ :en:phen. For the complex 2 it was resynthesized in ratio 1:1:4 to improve its yield. Greenish blue good crystals were isolated from the precipitate of 1 after re-crystallization from methanol while navy blue crystals can be isolated directly from the filtrate of 2 but its structure could not be refined. The complexes are non hygroscopic and thermally stable. They were obtained in fairly good yield and the $\mathrm{C}, \mathrm{H}$ and $\mathrm{N}$ analysis calculated agrees with the experimental value for the two complexes. The anions of the complexes are different in that there are no free phenanthroline and lattice water in 1 as found in 2 . This may be due to dissolution of the free phenanthroline and water during recrystallisation of precipitate of 1 . The complexes are soluble in methanol, ethanol, DMF, DMSO, acetonitrile and water. 


\subsection{Infrared Spectra}

The two complexes have almost similar IR absorption bands. Broad bands for $v\left(\mathrm{NH}_{2}\right)$ stretching vibration in 1,2-diaminoethane appeared at $3393 \mathrm{~cm}^{-1}, 3312 \mathrm{~cm}^{-1}$ for complex 1. Both asymmetric and symmetric $v(\mathrm{C}-\mathrm{H})$ bands in 1,2-diaminoethane could be seen at $2953 \mathrm{~cm}^{-1}$ and $2853 \mathrm{~cm}^{-1} . \mathrm{NH}_{2}$ deformation bands appeared at 1585 $\mathrm{cm}^{-1}$, while aromatic ring stretching vibration for phenanthroline occurs at $1507 \mathrm{~cm}^{-1}$. $\mathrm{ClO}_{4}$ band is observed at $1094 \mathrm{~cm}^{-1}$. Complex 2 also has similar bands as found in $1, v(\mathrm{O}-\mathrm{H})$, from uncoordinated water and $v\left(\mathrm{NH}_{2}\right)$ stretching band from 1,2-diaminoethane could be seen at $3403 \mathrm{~cm}^{-1}$ and $3226 \mathrm{~cm}^{-1}$ respectively while $v(\mathrm{C}-\mathrm{H})$ aromatic stretching vibrational band could be seen at $3093 \mathrm{~cm}^{-1}$, aromatic ring stretching occurred at 1506 $\mathrm{cm}^{-1}$ for the coordinated and at $1623 \mathrm{~cm}^{-1}$ for the uncoordinated phenanthroline rings. $\mathrm{NH}_{2}$ deformation band is found at $1585 \mathrm{~cm}^{-1}$ [9]. The IR result shows that the two complexes coordinated via the $\mathrm{N}$ atoms from the 1,2diaminoethane and from the $\mathrm{N}$ atoms of the aromatic rings. Molecules of water also present in complex 2 with free phenanthroline molecules. This is also confirmed from the $\mathrm{C}, \mathrm{H}, \mathrm{N}$ analysis. $\mathrm{Cu}-\mathrm{N}$ band could not be observed for phenanthroline as its absorb at relatively low frequency [9]. The $v(\mathrm{Cu}-\mathrm{N})$ from 1,2-diaminoethane for complexes 1 and 2 are 422 and $420 \mathrm{~cm}^{-1}$ respectively.

\subsection{Electronic Spectra}

The electronic absorption spectra of both complexes were measured in methanol solution. $\left[\mathrm{Cu}(\mathrm{en})(\mathrm{phen})_{2}\right]$ $\left(\mathrm{ClO}_{4}\right)_{2}$ absorb at $15.3 \times 10^{3} \mathrm{~cm}^{-1}(652 \mathrm{~nm})$, while $\left[\mathrm{Cu}(\right.$ en)(phen)2 $] \mathrm{Br}_{2} \cdot 2$ phen $\cdot 8 \mathrm{H}_{2} \mathrm{O}$ absorb at $15.3 \times 10^{3}$ $\mathrm{cm}^{-1}(646 \mathrm{~nm})$. (Figures 1(a) and (b)). All the four $\mathrm{d}-\mathrm{d}$ transitions of the rhombic distorted octahedral copper(II) chromophore may be placed within the broad envelop of the observed band. The energy band in this position for the two complexes is typically expected for a rhombic distorted octahedral configuration and may be assigned to ${ }^{2} \mathrm{E}_{\mathrm{g}} \rightarrow{ }^{2} \mathrm{~T}_{2 \mathrm{~g}}$ transition [10].

\subsection{Thermal Gravimetric Analysis}

Thermal gravimetric studies and differential thermal analysis were carried out on the complexes in the temperature range of $50^{\circ} \mathrm{C}$ to $800^{\circ} \mathrm{C}$ at a heating rate of $10^{\circ} \mathrm{C}$ / min. The measurements were done primarily to determine the composition of materials and to predict their thermal stability and also to determine extent of weight loss or gain due to decomposition, oxidation or dehydration. The thermal analysis shows that there are two broad endothermic peaks in the differential thermal analysis curve of the bromide analogue which is typical of dehydration reaction [11], whereas the perchlorate analogue showed three sharp endothermic peaks which shows changes in the crystalline or fusion process in the complex. The two

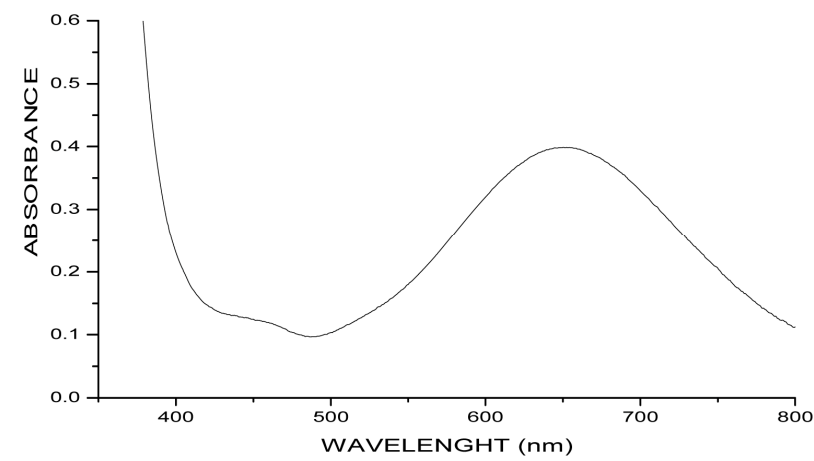

(a)

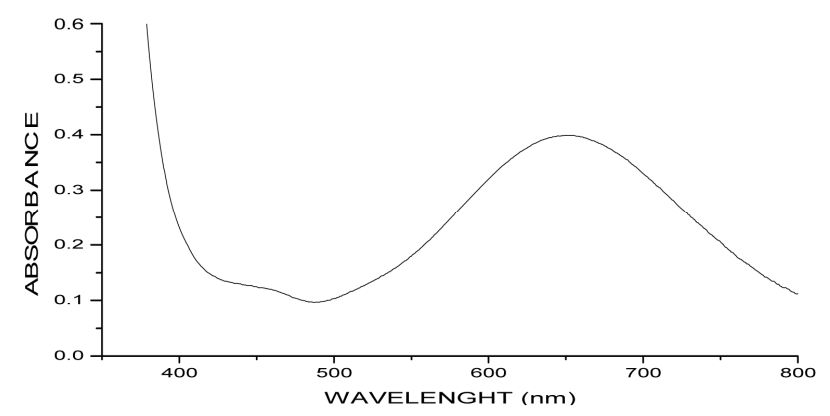

(b)

Figure 1. (a) UV-Visible spectra of $\left[\mathrm{Cu}(\mathrm{en})(\mathrm{phen})_{2}\right]_{2} \mathrm{phen} \cdot 2 \mathrm{Br} \cdot 8 \mathrm{H}_{2} \mathrm{O}$; (b) UV-Visible spectra of $\left.\left[\mathrm{Cu}(\mathrm{en})(\mathrm{phen})_{2}\right] \cdot 2 \mathrm{CIO}_{4}\right)^{-}$.

complexes showed no weight loss up to $170^{\circ} \mathrm{C}$ indicating the absence of uncoordinated water molecules in the complexes. The bromo complex decomposes in two endothermic peaks the first step occurs from $55^{\circ} \mathrm{C}-300^{\circ} \mathrm{C}$ and this corresponds to the loss of the eight $\mathrm{H}_{2} \mathrm{O}$ molecules and second from $300^{\circ} \mathrm{C}-500^{\circ} \mathrm{C}$ represent the decomposition of the organic part. The perchlorate decomposes with two peaks the first from $150^{\circ} \mathrm{C}-250^{\circ} \mathrm{C}$ then to $350^{\circ} \mathrm{C}$. The remaining organic part decomposes with the peak occurring from $350^{\circ} \mathrm{C}-650^{\circ} \mathrm{C}$.

\subsection{Structure of $\left[\mathrm{Cu}(\mathrm{en})(\mathrm{phen})_{2}\right]\left(\mathrm{ClO}_{4}^{-}\right)_{2}(1)$}

The molecular structure of complex 1 was established by single crystal X-ray study. The crystal system in 1 is orthorhombic with space group Pbcn (Table 1). The coordination sphere of copper consists of one 1,2-diaminoethane and two phenanthroline molecules with distorted octahedral geometry. The equatorial plane of hexa coordinated copper consists of both nitrogen atoms of 1,2diaminoethane molecule and nitrogen from the two phenanthroline molecules (Figure 2(a)). Two perchlorate anions also present in the lattice, there are no water molecules. The equatorial distances are Cu1-N1: 2.370 (2), Cu1-N2: 2.036 (2) $\AA$ and Cu1-N4: 2.367 (2) $\AA$ and Cu1-N5: 2.036 (2) $\AA$, while the axial distances are $\mathrm{Cu} 1-$ N3: 2.054 (2) $\AA$ and Cu1-N6: 2.042 (2) $\AA$ compared to the bond distances of its nitrate and chloride ions analogy 
Table 1. Crystallographic data for $\left[\mathrm{Cu}(\mathrm{en})(\mathrm{phen})_{2}\right] \cdot\left(\mathrm{ClO}_{4}\right)_{2}(1)$.

\begin{tabular}{|c|c|}
\hline & 1 \\
\hline Formula & $\mathrm{C}_{26} \mathrm{H}_{24} \mathrm{CuN}_{6} \mathrm{Cl}_{2} \mathrm{O}_{8}$ \\
\hline Formula weight & 682.95 \\
\hline Colour & Blue \\
\hline Crystal system & Orthorhombic \\
\hline$a(\AA)$ & $18.4895(12)$ \\
\hline$b(\AA)$ & $13.2926(9)$ \\
\hline$c(\AA)$ & $22.9599(15)$ \\
\hline$\alpha\left({ }^{\circ}\right)$ & 90.00 \\
\hline$\beta\left({ }^{\circ}\right)$ & 90.00 \\
\hline$\gamma\left(\left(^{\circ}\right)\right.$ & 90.00 \\
\hline $\mathrm{V}\left(\AA^{3}\right)$ & $5642.9(6)$ \\
\hline$Z$ & 8 \\
\hline Space group & Pbcn \\
\hline $\mathrm{T}\left({ }^{\circ} \mathrm{C}\right)$ & $110(2)$ \\
\hline$\lambda(\AA)$ & 0.71073 \\
\hline $\mathrm{D}_{\text {calcd }}\left(\mathrm{g} \cdot \mathrm{cm}^{-3}\right)$ & 1.608 \\
\hline$\mu\left(\mathrm{mm}^{-1}\right)$ & 1.025 \\
\hline $\mathrm{F}(000)$ & 2792 \\
\hline Crystal size (mm) & $0.45 \times 0.35 \times 0.25$ \\
\hline$\theta$ range for data collection $\left({ }^{\circ}\right)$ & $1.80-28.29$ \\
\hline $\mathrm{h} / \mathrm{k} / 1$ & $-23,24 /-17,17 /-30,13$ \\
\hline Reflections collected/unique $\left[\mathrm{R}_{\text {int }}\right]$ & $32270 / 5695 / 0.0459$ \\
\hline Completeness to $2 \theta=25.00(\%)$ & 99.7 \\
\hline Refinement method & Full-matrix least-squares on $F^{2}$ \\
\hline Data/restraints/parameters & $5695 / 0 / 388$ \\
\hline Goodness of fit on $F^{2}$ & 1.049 \\
\hline \multicolumn{2}{|l|}{ Final $R$ indices $[I>2 \sigma(I)]$} \\
\hline$R 1$ & 0.0459 \\
\hline$w R 2$ & 0.1200 \\
\hline \multicolumn{2}{|l|}{$R$ indices (all data) } \\
\hline$R 1$ & 0.0548 \\
\hline$w R 2$ & 0.1269 \\
\hline
\end{tabular}

[4], which have $\mathrm{Cu}-\mathrm{N}_{1}: 2.390$ (2), $\mathrm{Cu}-\mathrm{N}_{2} 2.0608$ (17), $\mathrm{Cu}-\mathrm{N}_{3}: 2.0210$ (18) $\AA$ and 2.406 (3), 2.071 (3), 2.028 (3) $\AA$ respectively. Selected geometrical parameters are presented in Table 2. The packing diagram for 1 showing hydrogen bonding interactions as viewed along the b-axis is shown in Figure 2(b). There is H-bonding interaction between the hydrogen of N5 from 1,2-diaminoethane and from $\mathrm{O}_{2}$ and $\mathrm{O}_{6}$ from perchlorate ions $\left[\mathrm{N}-\mathrm{H}-\mathrm{O}_{2}=2.936 \AA, \mathrm{N}-\mathrm{H}-\mathrm{O}_{6}: 3.064\right] \AA$.

\subsection{Biological Activities}

The antibacterial and antifungi activities of the com-

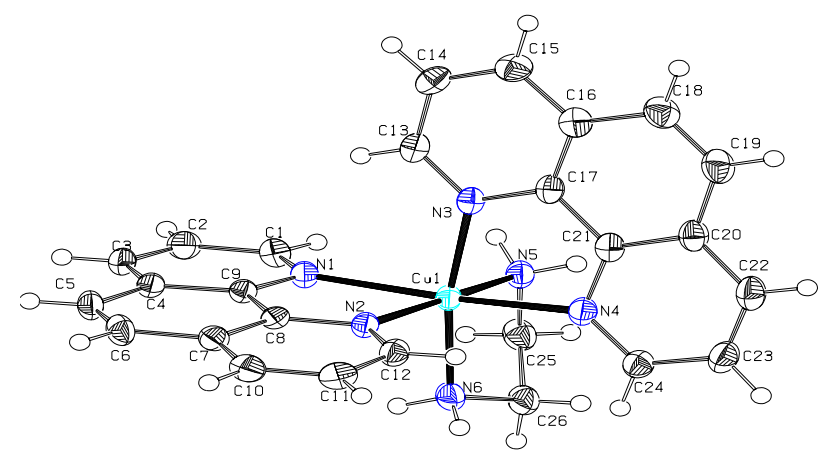

(a)

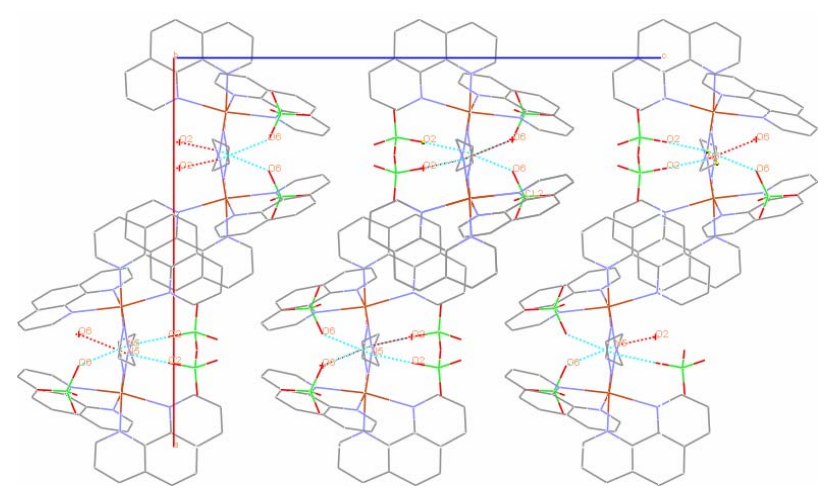

(b)

Figure 2. (a) ORTEP diagram depicting the cationic part of the copper complex with atom numbering scheme $(50 \%$ probability factor for the thermal ellipsoids); (b) Packing structure of complex 1 showing the $\mathrm{H}$-bonding between diaminoethane- $\mathrm{H}$ and $\mathrm{O}$-from perchlorate as viewed along the b-axis.

Table 2. Bond lengths and bond angles for $\left[\mathrm{Cu}(\mathrm{en})(\mathrm{phen})_{2}\right]$ $\left(\mathrm{ClO}_{4}\right)_{2}$.

\begin{tabular}{|c|c|c|}
\hline Bond $\mathrm{I}$ & Bor & $\left(^{\circ}\right)$ \\
\hline \multirow{2}{*}{$\mathrm{Cu} 1-$} & 8) & \\
\hline & N2 Cu1 N6 92.92 (8) & $\mathrm{C} 25 \mathrm{~N} 5$ \\
\hline Cu1-N2 2.036 (2) & N5 Cu1 N6 83.65 (9) & \\
\hline s & N2 Cu1 N3 92.33 (8) & $\mathrm{C} 25$ \\
\hline \multirow{2}{*}{ Cu1-N5 2.036 (2) } & N5 Cu1 N3 92.00 (8) & $\mathrm{Cu} 1$ \\
\hline & N6-Cu1-N3 169.91(8) & H5A N5 H5B 10 \\
\hline $\begin{array}{l}\text { Cu1-N6 } 2.042 \text { (2) } \\
\text { O1-C11 } 1.428(2)\end{array}$ & N2 Cu1 N4 96.53 (8) & $\mathrm{C} 26 \mathrm{I}$ \\
\hline O2-C11 1.4388 (19) & $\mathrm{N}_{5} \mathrm{C}$ & \\
\hline \multirow{2}{*}{ O3-C11 1.434 (2) } & N6-Cu1-N4 94.60 (8) & $\mathrm{Cu} 1 \mathrm{I}$ \\
\hline & N3 Cu1 N4 76.23 (8) & $\mathrm{C} 26 \mathrm{I}$ \\
\hline O4-C11 1.412 (2) & N2 Cu1 N1 75.96 (7) & H6A N6 H6B 108.4 (16 \\
\hline $\begin{array}{l}\text { O5-C12 } 1.429(3) \\
\text { O6-C12 } 1.449(3)\end{array}$ & N5 Cu1 N1 98.08 (8) & N1 C1 C2 123.6 (2) \\
\hline \multirow{3}{*}{$\begin{array}{l}\mathrm{O} 7-\mathrm{Cl} 21.409(3) \\
\mathrm{O} 8-\mathrm{Cl} 21.422(2)\end{array}$} & N6 Cu1 N1 92 & $\mathrm{~N} 1 \mathrm{C}$ \\
\hline & N3 Cu1 N1 96.79 (8) & $\mathrm{C} 2 \mathrm{C} 1 \mathrm{H} 111$ \\
\hline & N4 Cu1 N1 169.69 & $\mathrm{C} 3 \mathrm{C} 2 \mathrm{C} 11$ \\
\hline
\end{tabular}

plexes can easily be observed from Tables 3 and $\mathbf{4}$ and from the bar chart as seen in Figures 3-8. The data were obtained for the bacteria and fungi which cause diseases in man and plants with that of the standard drugs nor- 
mally used for these micro-organisms. From the results it can be observed that at higher concentrations the perchlorate analog have higher zone of inhibitions than their bromide counterpart when tested against the following bacteria: E. coli, P. aeruginosa, S. aureus and P. pyogenes compared to the zone of inhibitions observed with known antibiotics like Ampicillin and Chloralphenicol (Figures 3-6). The zones of inhibition are however lower when the values are compared to other antibiotics like Ciproflaxin and Norfloxacin. In general the results indicate that the complexes have potential and promising activity. Further investigations may however be required to illustrate the mechanisms by which the complexes exhibit its antibacterial effect [12].

Similarly, the perchlorate complex was more potent than the bromide complex as shown by the results of the zone of inhibition observed when tested with A. niger and C. albicans (Figures $\mathbf{7}$ and $\mathbf{8}$ ). Though the zones of inhibitions observed for standard antifungal drugs like Greseofulvin and Nystatin are higher than the ones observed for the complexes they are significant enough to indicate some antifungal properties inherent in the complexes.

Table 3. Zone of inhibition of complexes and the standard drugs against the bacteria $(\mathrm{mm})$.

\begin{tabular}{|c|c|c|c|c|c|c|c|c|c|c|c|c|c|c|c|c|c|c|c|c|}
\hline \multirow{2}{*}{$\begin{array}{c}\text { Bacteria species } \\
\text { Concn } \mu \mathrm{g} / \mathrm{ml}\end{array}$} & \multicolumn{5}{|c|}{ E. coli $\mathrm{MTCC} 443$} & \multicolumn{5}{|c|}{ P. aeruginosa MTCC 1688} & \multicolumn{5}{|c|}{ S. aureus MTCC 96} & \multicolumn{5}{|c|}{ S. pyogenes MTCC 442} \\
\hline & 5 & 25 & 50 & 100 & 250 & 5 & 25 & 50 & 100 & 250 & 5 & 25 & 50 & 100 & 250 & 5 & 25 & 50 & 100 & 250 \\
\hline CCLOENP & - & 15 & 17 & 19 & 24 & - & 14 & 15 & 18 & 21 & - & 11 & 14 & 18 & 21 & - & 13 & 15 & 17 & 18 \\
\hline CBRENP & - & 17 & 18 & 19 & 21 & 10 & 13 & 15 & 18 & 20 & - & 12 & 15 & 18 & 19 & - & 12 & 14 & 16 & 18 \\
\hline Amplicilline & 14 & 15 & 16 & 19 & 20 & 14 & 15 & 15 & 18 & 20 & 10 & 13 & 14 & 16 & 18 & 11 & 14 & 16 & 18 & 19 \\
\hline Chloramphenicol & 14 & 17 & 23 & 23 & 23 & 14 & 17 & 18 & 19 & 21 & 12 & 14 & 19 & 20 & 21 & 10 & 13 & 19 & 20 & 20 \\
\hline Ciprofloxacin & 20 & 23 & 28 & 28 & 28 & 20 & 23 & 24 & 26 & 27 & 17 & 19 & 21 & 22 & 22 & 16 & 19 & 21 & 21 & 22 \\
\hline Norfloxacin & 22 & 25 & 26 & 27 & 29 & 18 & 19 & 21 & 23 & 23 & 19 & 22 & 25 & 26 & 28 & 18 & 19 & 20 & 21 & 21 \\
\hline
\end{tabular}

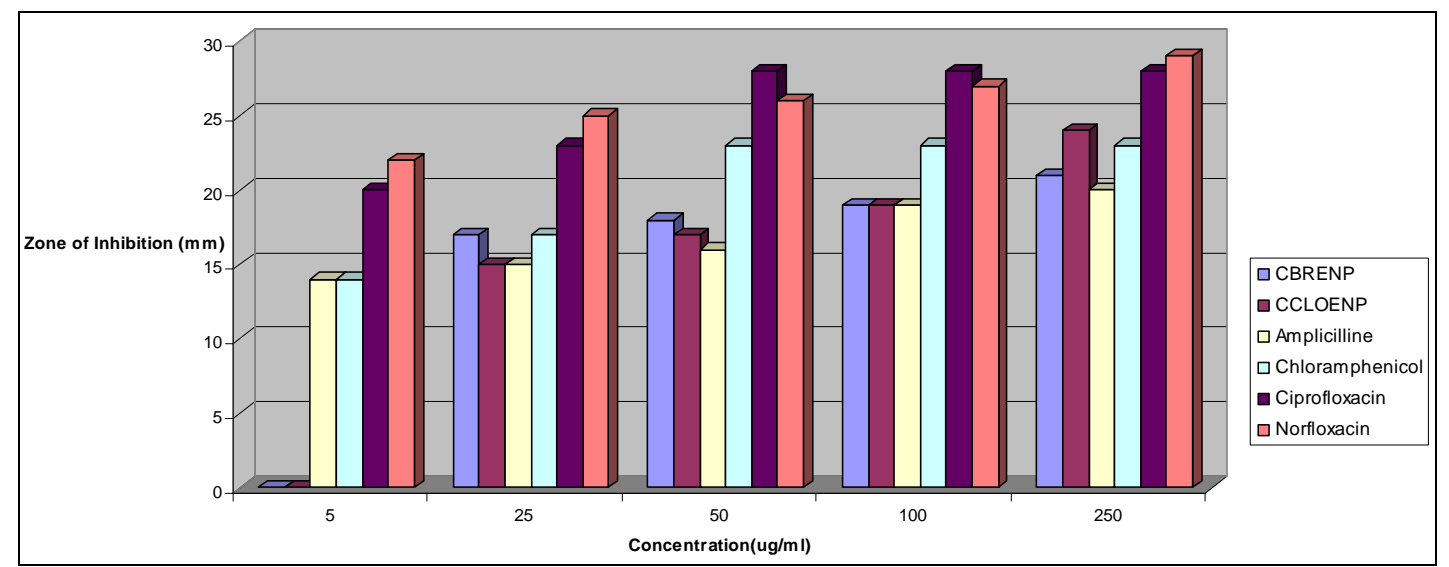

Figure 3. Zone of inhibition of E. coli against the concentration of the standard drugs and the complexes.

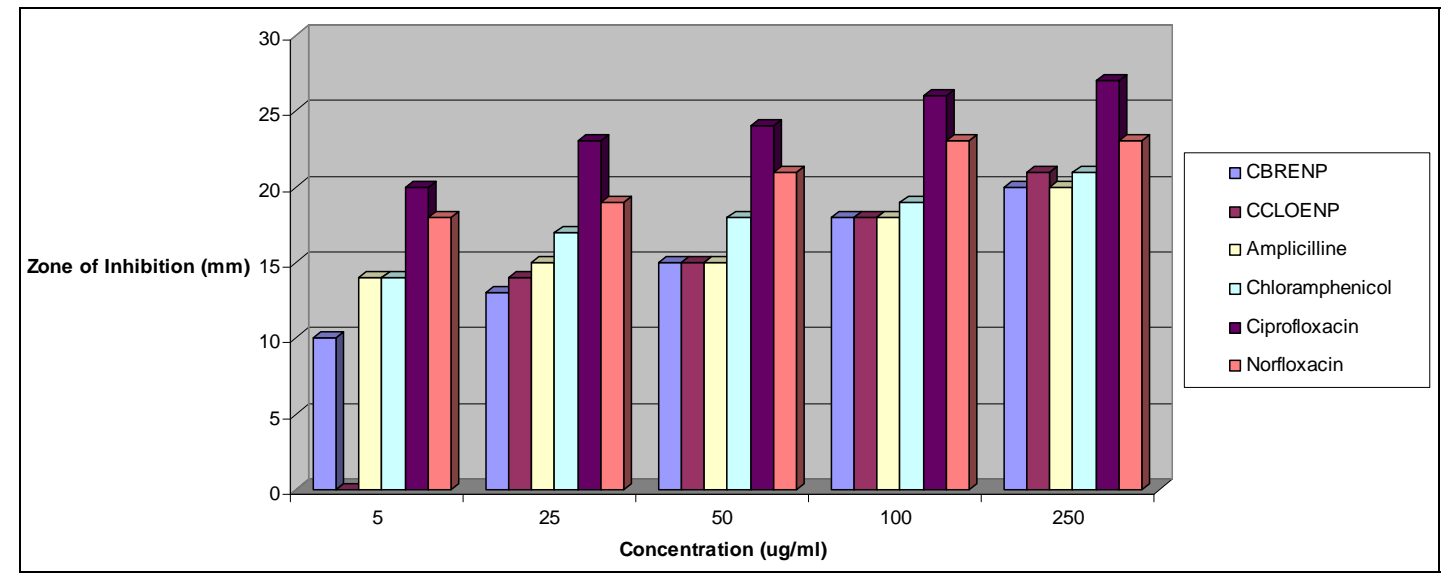

Figure 4. Zone of inhibition of $P$. aeruginosa against the concentration of the standard drugs and the complexes. 


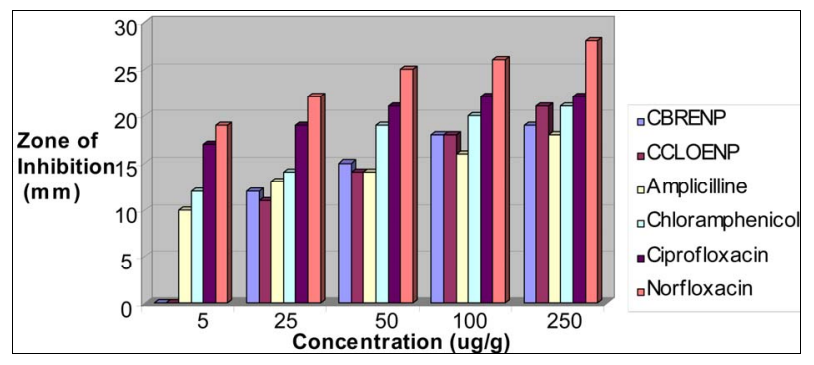

Figure 5. Zone of inhibition of $S$. aureus against the concentration of the standard drugs and the complexes.

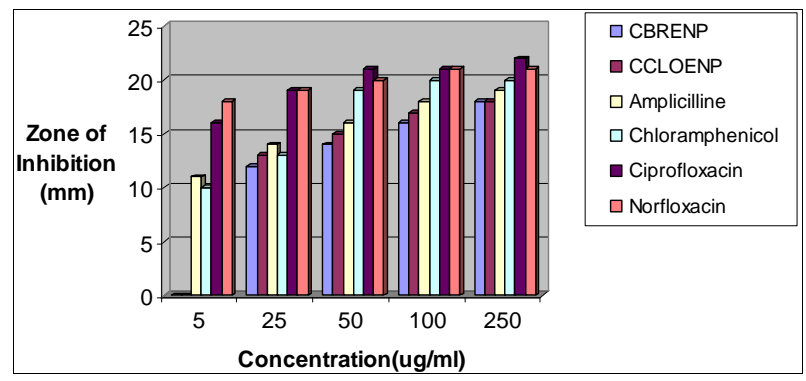

Figure 6. Zone of inhibition of $S$. ptogenes against the concentration of the standard drugs and the complexes.

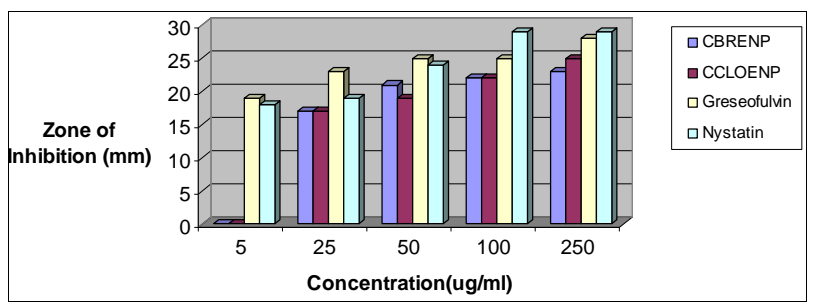

Figure 7. Zone of inhibition of $A$. niger against the standard drugs and the complexes.

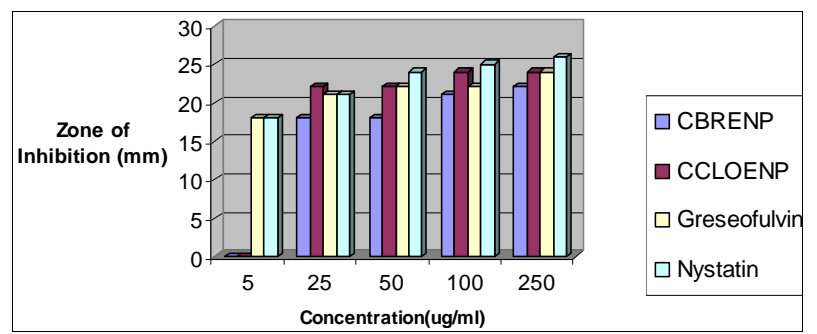

Figure 8. Zone of inhibition of C. albican against the concentration of the standard drugs and the complexes.

Table 4. Zone of inhibition of the complexes and the standard against the fungi (mm).

\begin{tabular}{cccccccccccc}
\hline Fungi species & \multicolumn{8}{c}{ A. niger MTCC 282} & \multicolumn{6}{c}{ C. albicans MTCC 227} \\
\hline Concn $\mu \mathrm{g} / \mathrm{ml}$ & 5 & 25 & 50 & 100 & 250 & 5 & 25 & 50 & 100 & 250 \\
CCLOENP & - & 11 & 14 & 18 & 21 & - & 13 & 15 & 17 & 18 \\
CBRENP & - & 12 & 15 & 18 & 19 & - & 12 & 14 & 16 & 18 \\
Greseofulvin & 19 & 23 & 25 & 25 & 28 & 18 & 21 & 22 & 22 & 24 \\
Nystatin & 18 & 19 & 24 & 29 & 29 & 18 & 21 & 24 & 25 & 26 \\
\hline
\end{tabular}

\section{CONCLUSION}

Two new mixed ligand complexes of copper(II) with two chelating ligands have been synthesized and characterized. Both complexes 1 and 2 have the same [ $\mathrm{Cu}(\mathrm{en})$ $\left.(\text { phen })_{2}\right]^{2+}$ cation, but differ in anionic part, though complex 1 has no water molecule, hydrogen bonding exists between the $\mathrm{H}$ in 1,2-diaminoethane and $\mathrm{O}$ from chlorate ion which form network within the lattice. The two complexes exhibit antimicrobial activities which are comparable to the known standard drugs used for some of the micro-organisms considered.

\section{ACKNOWLEDGEMENTS}

Onawumi O. O. thanks TWAS (The Academy of Science For Developing World) and CSIR (Council of Scientific and Industrial Research), New Delhi for the award of postdoctoral fellowship. Ladoke Akintola University of Technology, Nigeria is gratefully acknowledged for study leave. Dr. Parimal Paul is highly acknowledged for being a good host at CSMCRI, Bharvnagar, Gujurat. India. Thanks to Vinod K. Agarwal for I.R analysis, E. Suresh for determined the crystal structure. A. S. Onawumi is highly appreciated for his support. Microcare Laboratory at Unapani Road, Surat, India is gratefully acknowledged for conducting microbial experiments. Thanks to Mr. H. Brahmbhatt for technical assistance.

\section{REFERENCES}

[1] Lemoine, P., Viossat, B., Morgant, G., Greenaway, F.T., Tomas, A., Dung, N.H. and Sorenson, J.R.J. (2002) Synthesis, crystal structure, EPR properties, and anticonvulsant activities of binuclear and mononuclear 1,10-phenanthroline and salicylate ternary copper(II) complexes. Journal of Inorganic Biochemistry, 89, 18-28. doi:10.1016/S0162-0134(01)00324-5

[2] Devereux, M., Shea, D.O., Kellet, A., McCann, M., Walsh, M., Egan, D., Deggan, C., Kedziora, K., Rosair, G. and Muller-Bunz, H. (2007) Synthesis, X-ray crystal structures and biomimetic and anticancer activities of novel copper(II)benzoate complexes incorporating 2-(4'thiazolyl)benzimidazole (thiabendazole), 2-(2-pyridyl)benzimidazole and 1,10-phenanthroline as chelating nitrogen donor ligands. Journal of Inorganic Biochemistry, 10, 881-892. doi:10.1016/j.jinorgbio.2007.02.002

[3] Lave-Cambot, A., Cantnuel, M., Leydet, Y., Jonususkas, G., Bassani, D.M. and McClenaghan, N.D. (2008) Improving the photophysical properties of copper(I) bis (phenanthroline) complexes. Coordination Chemistry Reviews, 252, 2572-2584.

[4] Onawumi, O.O.E., OFaboya, O.P., Odunola, O.A., Prasad, T.K. and Rajasekharan, M.V. (2011) Mixed ligand trischelate of copper(II) with $N, N$-donor ligands-Synthesis, structure and spectra of $\left[\mathrm{Cu}(\mathrm{en})(\mathrm{phen})_{2}\right] \mathrm{X}_{2} \cdot 2 \mathrm{phen} \cdot 8 \mathrm{H}_{2} \mathrm{O}$ $\left(\mathrm{X}=\mathrm{Cl}^{-}, \mathrm{NO}_{3}^{-}\right)$. Polyhedron, 30, 725-729.

doi:10.1016/j.poly.2010.12.004 
[5] (2003) SAINTPLUS: Bruker AXS Inc., Madison.

[6] Sheldrick, G.M. (1996) SADABS: Program for empirical absorption correction. Universityof Göttingen, Göttingen.

[7] Sheldrick, G.M. (1997) SHELX-97: Programs for crystal structure analysis. University of Göttingen, Göttingen.

[8] Macrae, C.F., Edgington, P.R., McCabe, P., Pidcock, E., Shields, G.P., Taylor, R., Towler, M. and van de Streek, J. (2006) Mercury: Visualization and analysis of crystal structures. Journal of Applied Crystallography, 39, 453. doi:10.1107/S002188980600731X

[9] Nakamoto K. (1963) Infrared and Raman spectra of inorganic and coordination compounds. John Willey and
Sons, New York, 155.

[10] Lever, A.B.P. (1984) Inorganic electronic spectroscopy. Elsevier, Amsterdam.

[11] Kaur H. (2010) Instrumental methods of chemical analysis. 6th Edition, Pragati Prakashan Publishers, Meerut, 991.

[12] Prakesh, A. and Singh, M.P.G.K. (2011) Synthesis spectroscopy and biological studies of nickel(II) complexes with tertradentate schiff bases having $\mathrm{N}_{2} \mathrm{O}_{2}$ donor group. Journal of Developmental Biology and Tissue Engineering, 3, 13-19. 


\section{APPENDIX}

CCDC 870713 contain the supplementary crystallographic data for compound 1 . These data can be obtained free of charge via http://www.ccdc.cam.ac.uk/conts/retrieving.html, or from the Cambridge Crystallographic Data Centre, 12 Union Road, Cambridge CB2 1EZ, UK; fax: (+44) 1223336-033; or e-mail: deposit@ccdc.cam.ac.uk.

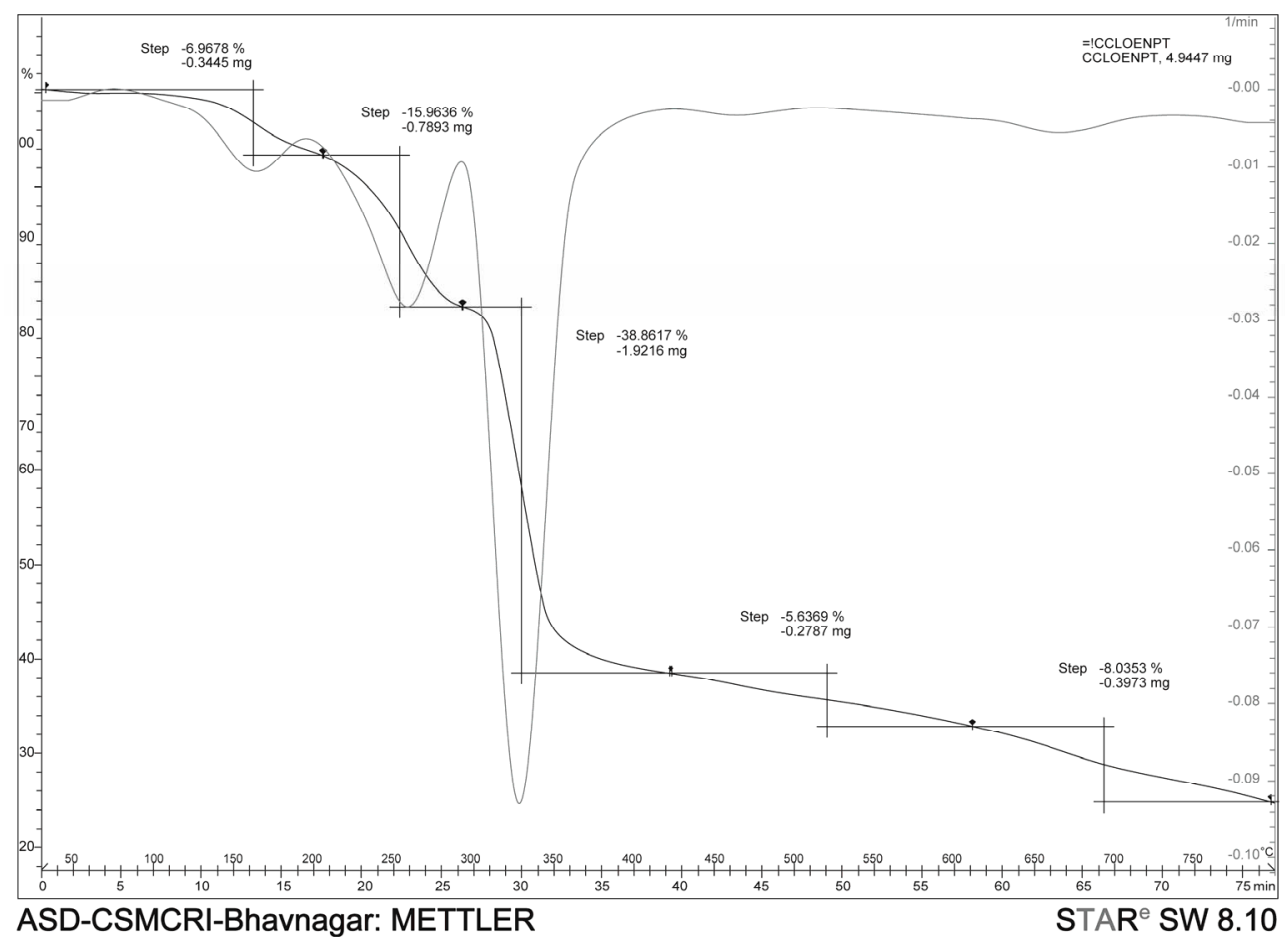

Thermogravimetric analysis of $\left[\mathrm{Cu}(\mathrm{en})(\text { phen })_{2}\right]\left(\mathrm{ClO}_{4}\right)_{2}$.

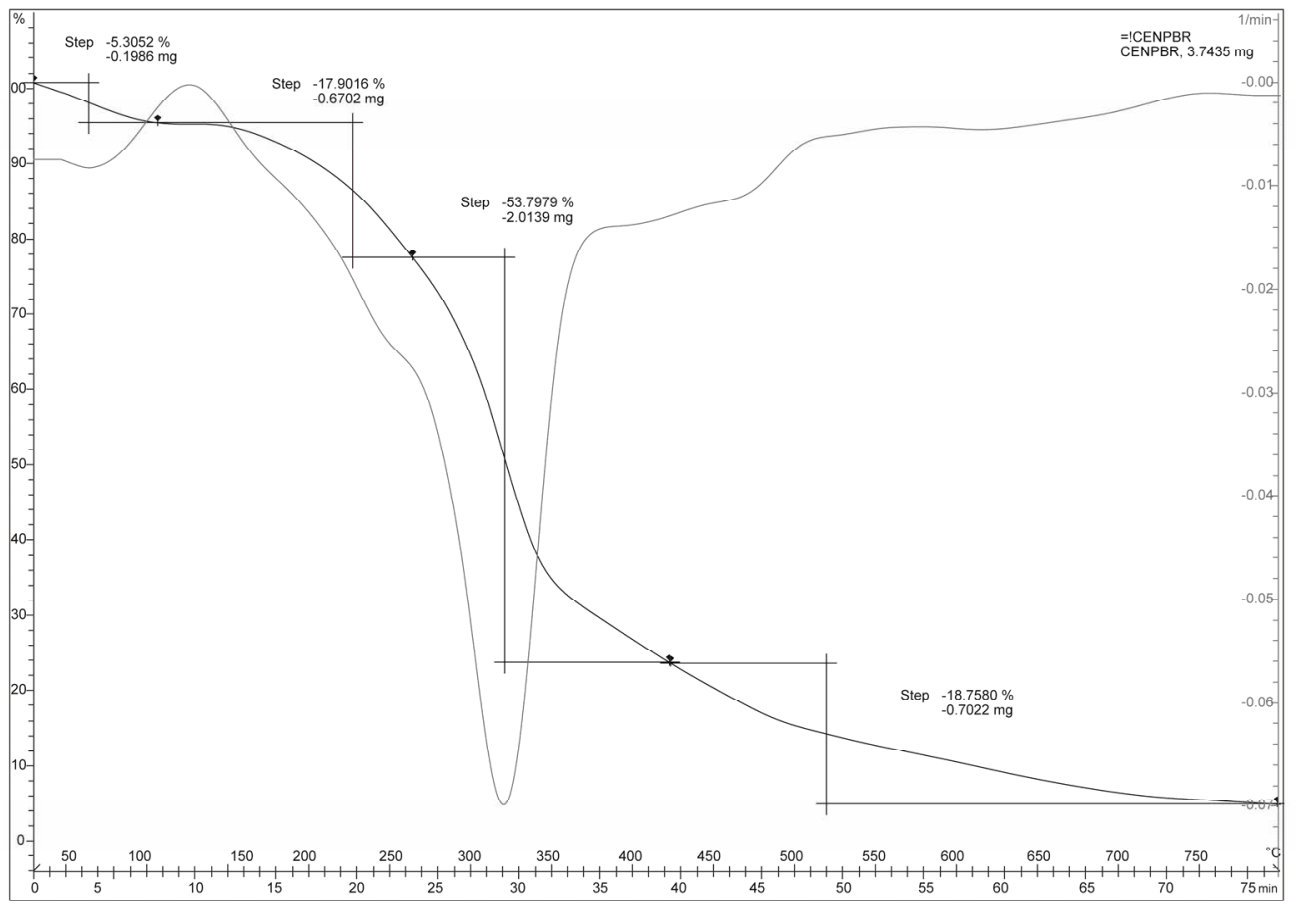

ASD-CSMCRI-Bhavnagar: METTLER

STAR SW 8.10

Thermogravimetric analysis of $\left[\mathrm{Cu}(\mathrm{en})(\mathrm{phen})_{2}\right] \mathrm{Br}_{2} \cdot 2 \mathrm{phen} \cdot 8 \mathrm{H}_{2} \mathrm{O}$. 